\title{
The Level of Serum Granulocyte Colony-Stimulating Factor in Cancer Patients with Leukocytosis
}

\author{
Akemi Kubo Shimasaki, Kyoji Hirata, Tetsuji Kawamura, Nobuya Kunibe, Kenzo Hirai, \\ Kenrou Yoshimoto, Hisako Hashimoto, Yasuharu NaKahara and Yoshirou Mochizuki
}

The level of serum granulocyte colony-stimulating factor (G-CSF) obtained from patients with leukocytosis $(>10,000 / \mu \mathrm{l})$ between May 1989 and April 1991 was measured by enzyme immunoassay. Studied were 18 patients with malignant neoplasms (median age, 64 years) and 14 patients with hematologic disease (median age, 59 years). Increased serum G-CSF values ranging from 70 to $374 \mathrm{pg} / \mathrm{ml}$ were noted in 7 of 15 lung cancer cases, a case of malignant thymoma and a blastic crisis of chronic myelogenous leukemia. The rest of the cases showed a normal value $(<60 \mathrm{pg} / \mathrm{ml})$. There was no correlation between the neutrophil count and G-CSF level. In lung cancer cases with high G-CSF values, neither a characteristic histologic type nor common elevation of tumor markers could be seen. The neutrophil alkaline phosphatase score was significantly increased and hypercalcemia was presented in high G-CSF cases. G-CSF may contribute at least in part to unknown leukocytosis observed in malignant neoplasms, especially in lung cancer.

(Internal Medicine 31: 861-865, 1992)

Key words: lung cancer, NAP, hypercalcemia

\section{Introduction}

The generation of granulocyte colony-stimulating factor (G-CSF) by monocytes, macrophages, fibroblasts and endothelial cells increases in response to infection (1) or neutropenia (2), via interactions of cytokines such as interleukin-1 (3) and tumor necrosis factor (1). Recently, recombinant human G-CSF has become available for clinical use and has contributed to the improvement of therapeutic results.

Leukocytosis is frequently noted among patients with cancer. A granulopoietic factor produced by malignant tumor was reported by Robinson (4), and Asano et al. (5) who demonstrated colony-stimulating activity in the plasma of patients with lung cancer provided evidence for the occurrence of G-CSF producing tumors. We previously reported G-CSF production by an established cell line derived from a patient with hepatoma (6).

In the present study, G-CSF levels in sera from patients with leukocytosis were examined and assessed to explore the potential contribution of circulating G-CSF in the development of leukocytosis in malignant neoplasms, compared with hematologic diseases.

\section{Subjects and Methods}

Thirty-two patients with leukocytosis $(>10,000 / \mu \mathrm{l})$ between May 1989 and April 1991 were studied. They had no evidence of infection, nor influence of drugs at the time of the study. Of 18 patients with malignant neoplasms, the majority were lung cancer (15) and the remainder were a case each of malignant thymoma, malignant mesothelioma and prostatic cancer. There were 14 men and 4 women and their median age was 64 years ( 43 to 78 years). Of these, 14 patients ( 10 men, 4 women, median age $59 ; 38$ to 72 years) had hematologic diseases; 3 patients with chronic myelogenous leukemia (CML, with blastic crisis in 2), 2 with chronic neutrophilic leukemia (CNL), 2 in the leukemic phase of chronic myelomonocytic leukemia (CMMoL), 2 with polycythemia vera, 1 with essential thrombocythemia and 4 with unclassified myeloproliferative disorder (MPD). Eight other cases of lung cancer without leukocytosis served as control.

The level of serum G-CSF was determined by enzyme

From the Department of Internal Medicine, Himeji National Hospital, Himeji

Received for publication August 12, 1991; Accepted for publication March 10, 1992

Reprint requests should be addressed to Dr. Akemi Kubo Shimasaki, the Department of Internal Medicine, Himeji National Hospital, Honmachi68 , Himeji 670 , Japan 
immunoassay (7) at the Research Laboratories of Chugai Pharmaceutical Co. Ltd. Briefly, $0.2 \mathrm{ml}$ of standards or unknowns were dispensed into the anti-recombinant G-CSF antibody-coated tubes followed by $0.5 \mathrm{ml}$ of reaction buffer. After 2 hours of incubation at room temperature, horseradish peroxidase-labelled antirecombinant $\mathrm{G}$-CSF antibody $(0.1 \mathrm{ml})$ was added and the tubes were further incubated for 2 hours at room temperature. The tubes were washed 3 times with washing buffer and $1 \mathrm{ml}$ of substrate solution was added to each. After a 1 hour incubation at room temperature, the reaction was stopped with $1 \mathrm{ml}$ of $4 \mathrm{~N} \mathrm{H}_{2} \mathrm{SO}_{4}$ and the absorbance was measured at $492 \mathrm{~nm}$. The G-CSF levels of healthy volunteers were less than $30 \mathrm{pg} / \mathrm{ml}$ (2). In routine measurement, the sensitivity of this assay was $60 \mathrm{pg} / \mathrm{ml}$.

Sera were obtained from patients prior to institution of therapy as a rule. In cases where the patient had previously been or was being treated, blood was obtained at least one month after conclusion of the course of therapy for malignant neoplasms or during continued maintenance drug therapy for hematologic diseases.

\section{Results}

The serum G-CSF levels in patients with malignant neoplasms are shown in Table 1 . Twelve of 18 cases were untreated at the time of study. None had evidence of overt infection but nearly all patients showed a positive test for $\mathrm{C}$-reactive protein and 2 patients had a fever. Seven cases of lung cancer and one case of malignant thymoma showed high levels of serum G-CSF, with a range of 71 to $374 \mathrm{pg} / \mathrm{ml}$ (neutrophil count, 7,300 to $57,100 / \mu \mathrm{l}$ ). The differential count of leukocytes revealed an overwhelming predominance of mature neutrophils and a leukemoid reaction was seen in only 3 cases. The present series showed no correlation of neutrophil count with serum G-CSF level (correlation coefficient, $0.07,0.5<\mathrm{p}<1$ ). An increase in the monocyte count of over $1,000 / \mu \mathrm{l}$ was recognized in 3 patients among those with high serum $G$ CSF levels. There was no correlation between monocyte count and serum G-CSF level (correlation coefficient, $0.69,0.05<\mathrm{p}<0.1$ ). The serum level of G-CSF was under $60 \mathrm{pg} / \mathrm{ml}$ in all 8 lung cancer patients with a total leukocyte count of less than $10,000 / \mu$ l (Table 2).

Table 3 shows serum G-CSF levels of patients with hematologic diseases. Ten of 14 cases, excluding CMMoL and blastic crisis of CML, were untreated at the time of study. Total leukocyte count exhibited a marked increase as high as $382,800 / \mu \mathrm{l}$ (neurophil count, 7,400 to $49,800 / \mu \mathrm{l}$ ) while the serum G-CSF level was less than $60 \mathrm{pg} / \mathrm{ml}$ in all cases except in one case of blastic crisis in CML which showed an elevation to $70 \mathrm{pg} / \mathrm{ml}$.

Table 4 shows the histologic types and tumor markers in the 7 cases of lung cancer with high serum G-CSF levels. There was no characteristic histologic type in relation to the serum G-CSF elevation (adenocarcinoma, 2 cases; large cell carcinoma, 1; squamous cell carcinoma, 2; and unknown, 2). Serum assay data on tumor markers, which included squamous cell carcinoma related antigen $(\mathrm{SCC})$, sialyl $\mathrm{Le}^{\mathrm{x}}$-i antigen (SLX), carcinoembryonic antigen (CEA), carbohydrate antigen (CA) 19-9, and neuronspecific enolase (NSE), also did not reveal any common elevation in these cases.

The neutrophil alkaline phosphatase (NAP) score and serum calcium level in 9 patients with high serum G-CSF values are shown in Table 5 . The mean \pm S.E. of the NAP score in lung caner patients with a high G-CSF

Table 1. Serum G-CSF Level in Malignant Neoplasms with Leukocytosis

\begin{tabular}{|c|c|c|c|c|c|c|c|c|c|c|}
\hline \multirow{2}{*}{\multicolumn{2}{|c|}{ Paticnt }} & \multirow{2}{*}{ Disease } & \multirow{2}{*}{$\begin{array}{l}\text { WBC } \\
\mid \mu l\end{array}$} & \multicolumn{3}{|c|}{ Neutro $\%$} & \multirow{2}{*}{$\begin{array}{l}\text { Mono } \\
\%\end{array}$} & \multirow{2}{*}{$\begin{array}{l}\text { CRP } \\
\mathrm{mg} / \mathrm{dl}\end{array}$} & \multirow{2}{*}{ Fever } & \multirow{2}{*}{$\begin{array}{l}\mathrm{G}-\mathrm{CSF} \\
\mathrm{pg} / \mathrm{ml}\end{array}$} \\
\hline & & & & Immature & Stab & Seg & & & & \\
\hline KM & $43 \mathrm{M}$ & Lung ca & 59,500 & 0 & 0 & 96 & 3 & 12.5 & $(+)$ & 206 \\
\hline $\mathrm{KA}$ & $47 \mathrm{M}$ & Lung ca & 57,100 & 0 & 1 & 94 & 3 & 16.6 & $(+)$ & 72 \\
\hline YT & $72 \mathrm{~F}$ & Lung ca & 34,700 & 5 & 5 & 75 & 7 & 4.39 & $(-)$ & 374 \\
\hline $\mathrm{KT}$ & $50 \mathrm{~F}$ & Thymoma & 27,500 & 2 & 0 & 96 & 1 & 5.57 & $(-)$ & 81 \\
\hline TM & $70 \mathrm{M}$ & Lung ca & 23,800 & 13 & 4 & 77 & 4 & 4.1 & $(-)$ & 118 \\
\hline ST & $63 \mathrm{~F}$ & Lung ca & 18,500 & 0 & 0 & 74 & 7 & 24.4 & $(-)$ & $<60$ \\
\hline $\mathrm{TI}$ & $78 \mathrm{M}$ & Lung ca & 16,600 & 0 & 1 & 94 & 4 & 1.12 & $(-)$ & 166 \\
\hline NM & $63 \mathrm{M}$ & Lung ca & 16,000 & 0 & 0 & 56 & 6 & 1.64 & $(-)$ & $<60$ \\
\hline $\mathrm{KH}$ & $65 \mathrm{M}$ & Lung ca & 15,600 & 0 & 0 & 95 & 5 & 0.34 & $(-)$ & $<60$ \\
\hline MK & $75 \mathrm{M}$ & Mesothelioma & 14,200 & 0 & 0 & 73 & 5 & 1.01 & $(-)$ & $<60$ \\
\hline MY & $63 \mathrm{M}$ & Lung ca & 14,100 & 0 & 0 & 64 & 5 & 0.6 & $(-)$ & 172 \\
\hline $\mathrm{KI}$ & $66 \mathrm{M}$ & Lung ca & 14,100 & 0 & 0 & 52 & 5 & 2.4 & $(-)$ & 71 \\
\hline $\mathrm{RM}$ & $60 \mathrm{M}$ & Lung ca & 14,000 & 0 & 0 & 71 & 4 & 9.24 & $(-)$ & $<60$ \\
\hline $\mathrm{HT}$ & $74 \mathrm{M}$ & Lung ca & 12,000 & 0 & 1 & 79 & 5 & 1.38 & $(-)$ & $<60$ \\
\hline $\mathrm{TI}$ & $52 \mathrm{~F}$ & Lung ca & 11,600 & 0 & 0 & 82 & 6 & 1.14 & $(-)$ & $<60$ \\
\hline SF & $71 \mathrm{M}$ & Lung ca & 11,500 & 0 & 0 & 55 & 6 & 1.66 & $(-)$ & $<60$ \\
\hline $\mathrm{KM}$ & $71 \mathrm{M}$ & Lung ca & 11,400 & 0 & 0 & 54 & 5 & 0.27 & $(-)$ & $<60$ \\
\hline YH & $71 \mathrm{M}$ & Prostatic ca & 11,300 & 0 & 0 & 69 & 7 & $<0.25$ & $(-)$ & $<60$ \\
\hline
\end{tabular}


Serum G-CSF level in Cancer Patients

Table 2. Serum G-CSF Level in Lung Cancer Cases without Leukocytosis

\begin{tabular}{|c|c|c|c|c|c|c|c|c|c|c|}
\hline \multirow{2}{*}{\multicolumn{2}{|c|}{ Patient }} & \multirow{2}{*}{ Histology } & \multirow{2}{*}{$\begin{array}{l}\text { WBC } \\
/ \mu \mathrm{l}\end{array}$} & \multicolumn{3}{|c|}{ Neutro \% } & \multirow[b]{2}{*}{$\begin{array}{l}\text { Mono } \\
\%\end{array}$} & \multirow[b]{2}{*}{$\begin{array}{l}\text { CRP } \\
\mathrm{mg} / \mathrm{dl}\end{array}$} & \multirow{2}{*}{ Fever } & \multirow[b]{2}{*}{$\begin{array}{l}\text { G-CSF } \\
\mathrm{pg} / \mathrm{ml}\end{array}$} \\
\hline & & & & Immature & Stab & Seg & & & & \\
\hline $\mathrm{AK}$ & $64 \mathrm{M}$ & Adeno + Squ & 9,800 & 0 & 0 & 66 & 3 & 1.03 & $(-)$ & $<60$ \\
\hline $\mathrm{FY}$ & $61 \mathrm{M}$ & Adeno & 9,400 & 0 & 0 & 77 & 6 & 5.61 & $(-)$ & $<60$ \\
\hline $\mathrm{KI}$ & $68 \mathrm{M}$ & Large cell & 8,200 & 0 & 0 & 71 & 7 & 1.8 & $(-)$ & $<60$ \\
\hline MY & $48 \mathrm{M}$ & Squamous & 7,200 & 0 & 0 & 50 & 5 & 1.67 & $(-)$ & $<60$ \\
\hline SI & $71 \mathrm{M}$ & unknown & 6,800 & 0 & 0 & 70 & 7 & 0.54 & $(-)$ & $<60$ \\
\hline SM & $55 \mathrm{M}$ & Squamous & 6,600 & 0 & 2 & 51 & 5 & $<0.25$ & $(-)$ & $<60$ \\
\hline MK & $86 \mathrm{M}$ & Adeno & 6,200 & 0 & 0 & 66 & 3 & $<0.25$ & $(-)$ & $<60$ \\
\hline $\mathrm{HN}$ & $80 \mathrm{M}$ & Squamous & 6,000 & 0 & 0 & 48 & 8 & $<0.25$ & $(-)$ & $<60$ \\
\hline
\end{tabular}

Table 3. Serum G-CSF Level in Hematologic Diseases with Leukocytosis

\begin{tabular}{|c|c|c|c|c|c|c|c|c|c|c|}
\hline \multirow{2}{*}{\multicolumn{2}{|c|}{ Patient }} & \multirow{2}{*}{ Discase } & \multirow{2}{*}{$\begin{array}{l}\text { WBC } \\
/ \mu \mathrm{l}\end{array}$} & \multicolumn{3}{|c|}{ Neutro \% } & \multirow[b]{2}{*}{$\begin{array}{l}\text { Mono } \\
\%\end{array}$} & \multirow[b]{2}{*}{$\begin{array}{l}\text { CRP } \\
\mathrm{mg} / \mathrm{dl}\end{array}$} & \multirow{2}{*}{ Fever } & \multirow[b]{2}{*}{$\begin{array}{l}\text { G-CSF } \\
\mathrm{pg} / \mathrm{ml}\end{array}$} \\
\hline & & & & Immature & Stab & Seg & & & & \\
\hline MT & $65 \mathrm{M}$ & CMMoL & 382,800 & 86 & 6 & 7 . & 0 & 0.75 & $(-)$ & $<60$ \\
\hline MO & $59 \mathrm{~F}$ & CML crisis & 93,400 & 74 & 3 & 26 & 0 & 6.38 & $(+)$ & $<60$ \\
\hline SK & $42 \mathrm{~F}$ & CML crisis & 81,000 & 30 & 0 & 19 & 0 & 3.74 & $(-)$ & 70 \\
\hline SS & $63 \mathrm{M}$ & CMMoL & 40,500 & 25 & 1 & 68 & 1 & $<0.25$ & $(-)$ & $<60$ \\
\hline ST & $57 \mathrm{M}$ & $\mathrm{CNL}$ & 39,300 & 0 & 3 & 72 & 2 & $<0.25$ & $(-)$ & $<60$ \\
\hline SM & $69 \mathrm{M}$ & MPD & 35,700 & 1 & 0 & 82 & 2 & $<0.25$ & $(-)$ & $<60$ \\
\hline TO & $72 \mathrm{M}$ & Polycythemia & 25,100 & 0 & 0 & 78 & 1 & $<0.25$ & $(-)$ & $<60$ \\
\hline $\mathrm{KM}$ & $69 \mathrm{M}$ & Polycythemia & 23,600 & 0 & 1 & 85 & 6 & 4.19 & $(-)$ & $<60$ \\
\hline SM & $61 \mathrm{M}$ & Thrombocythemia & 19,500 & 0 & 0 & 51 & 8 & $<0.25$ & $(-)$ & $<60$ \\
\hline TM & $63 \mathrm{~F}$ & $\mathrm{CNL}$ & 17,200 & 0 & 0 & 82 & 3 & $<0.25$ & $(-)$ & $<60$ \\
\hline HT & $38 \mathrm{M}$ & $\mathrm{CML}$ & 15,100 & 1 & 1 & 60 & 3 & $<0.25$ & $(-)$ & $<60$ \\
\hline HS & $69 \mathrm{~F}$ & MPD & 13,800 & 0 & 2 & 64 & 0 & $<0.25$ & $(-)$ & $<60$ \\
\hline IF & $56 \mathrm{M}$ & MPD & 13,400 & 0 & 0 & 68 & 5 & $<0.25$ & $(-)$ & $<60$ \\
\hline KH & $47 \mathrm{M}$ & MPD & 12,700 & 0 & 0 & 58 & 2 & $<0.25$ & $(-)$ & $<60$ \\
\hline
\end{tabular}

Table 4. Histologic Types and Tumor Markers in Lung Cancer Cases with High Serum G-CSF Levels

\begin{tabular}{|c|c|c|c|c|c|c|c|}
\hline \multirow{2}{*}{\multicolumn{2}{|c|}{ Patient }} & \multirow{2}{*}{ Histology } & \multicolumn{5}{|c|}{ Tumor marker } \\
\hline & & & $\begin{array}{l}\mathrm{SCC} \\
(<1.5 \mathrm{ng} / \mathrm{ml})\end{array}$ & $\begin{array}{l}\mathrm{SLX} \\
(<38 \mathrm{U} / \mathrm{ml})\end{array}$ & $\begin{array}{l}\text { CEA } \\
(<2.5 \mathrm{ng} / \mathrm{ml})\end{array}$ & $\begin{array}{l}\text { CA } 19-9 \\
(<37 \mathrm{U} / \mathrm{ml})\end{array}$ & $\begin{array}{l}\text { NSE } \\
(<10 \mathrm{ng} / \mathrm{ml})\end{array}$ \\
\hline $\mathrm{KM}$ & $43 \mathrm{M}$ & Adeno & 2.0 & 135.5 & 11.7 & 285.1 & 2.9 \\
\hline $\mathrm{KA}$ & $47 \mathrm{M}$ & Large cell & n.d. & n.d. & $<1.0$ & $<7.0$ & n.d. \\
\hline YT & $72 \mathrm{~F}$ & unknwon & 17.6 & 53.3 & 9.5 & 233.5 & 190.0 \\
\hline TM & $70 \mathrm{M}$ & Adeno & $<1.0$ & 29.1 & n.d. & n.d. & 26.0 \\
\hline TI & $78 \mathrm{M}$ & unknown & $<1.0$ & 33.0 & 1.3 & 19.3 & 16.0 \\
\hline MY & $63 \mathrm{M}$ & Squamous & 35.0 & 29.6 & 3.7 & 21.8 & 8.0 \\
\hline $\mathrm{KI}$ & $66 \mathrm{M}$ & Squamous & 15.0 & 18.4 & $<1.0$ & n.d. & 6.7 \\
\hline
\end{tabular}

n.d.: not done

level was $333.2 \pm 33.5(n=6)$, which was significantly greater than that in those with serum G-CSF values of less than $60 \mathrm{pg} / \mathrm{ml}(265.4 \pm 11.3, \mathrm{n}=14)$ (Wilcoxon test $0.005<\mathrm{p}<0.025$ ). Two patients with lung cancer and the patient with malignant thymoma had a high serum level of calcium in the present series.

\section{Discussion}

It is noteworthy that the incidence of serum G-CSF elevation was as high as $47 \%$ in lung cancer with leukocytosis. This indicates that frequency for elevation of serum G-CSF was $6 \%$ in the total lung cancer cases (approximately 120 cases) examined during the twoyear period of this study. A direct correlation of the neutrophil count and serum G-CSF level has been reported (2). Possible simultaneous elevation of M-CSF with G-CSF $(8,9)$ and/or possible participation of factors such as IL-3 and GM-CSF might account at least in part for the lack of a significant correlation of serum G-CSF 
Table 5. NAP Score and Serum Calcium Level in Patient with High Serum G-CSF Values

\begin{tabular}{llrrrrr}
\hline \multirow{2}{*}{ Patient } & Disease & G-CSF & \multicolumn{2}{c}{ NAP } & \\
\cline { 5 - 6 } & & & pg/ml & $\%$ & score & Ca \\
\hline YT & $72 \mathrm{~F}$ & Lung ca & 374 & 90 & 304 & 12.5 \\
KM & $43 \mathrm{M}$ & Lung ca & 206 & n.d. & n.d. & 11.5 \\
MY & $63 \mathrm{M}$ & Lung ca & 172 & 98 & 300 & 9.5 \\
TI & $78 \mathrm{M}$ & Lung ca & 166 & 92 & 312 & 8.6 \\
TM & $70 \mathrm{M}$ & Lung ca & 118 & n.d. & n.d. & 9.4 \\
KT & $50 \mathrm{~F}$ & Thymoma & 81 & 100 & 344 & 14.0 \\
KA & $47 \mathrm{M}$ & Lung ca & 72 & 100 & 489 & 7.7 \\
KI & $66 \mathrm{M}$ & Lung ca & 71 & 83 & 250 & 10.1 \\
SK & $42 \mathrm{~F}$ & CML crisis & 70 & 88 & 323 & 9.5 \\
\hline
\end{tabular}

n.d.: not done

level and neutrophil count in the present series. The presence of an inhibitor of G-CSF may be probable (10) and CSF activity might be demonstrated by the transplantation to nude mice although it could not be detected in serum (11). Further study is needed, therefore, to demonstrate G-CSF in tumor tissues and to assess its biological activity in individual cases, in order to clarify the potential relationship of G-CSF to leukocytosis in malignant tumors.

On the other hand, the rarity of serum G-CSF elevation in hematologic diseases would suggest that G-CSF is unlikely to contribute in any significant extent to the pathogenesis of leukocytosis even in CNL which is a proliferative disorder of mature neutrophils. This may be explained by the feedback mechanism (2). It would be important to consider possible participation of plural hematopoietic factors $(1,3)$, such as the possibility of leukocytosis developing through cooperation of G-CSF and M-CSF (8). Furthermore, assessment of the sensitivity to CSF of myeloid precursor (CFU-C) is also important, from the viewpoints of 1 ) the reported findings of endogenous CFU-C proliferation in some cases of MPD (12) and 2) the fact that there is no significant correlation between serum G-CSF level and bone marrow CFU-C (13).

It was reported that large cell carcinoma is the most common histologic type of CSF-producing lung cancer (14). However, no characteristic features such as common histologic types or elevation of circulating tumor markers could be noted in the present series. The increase in NAP score seen in the cases exhibiting serum G-CSF elevation reflects promotion of neutrophil maturation by G-CSF (15) via its NAP-inducing effect $(16,17)$. Hypercalcemia in patients with G-CSF-producing carcinoma of the lung has been reported $(18,19)$, and it might be attributed to a PTH-like factor elaborated by the tumor $(19,20)$.

Unlike the leukocytosis in hematologic diseases, G-CSF may be implicated in the genesis of unknown leukocytosis in malignant neoplasms. The fact that
G-CSF receptor presents on tumor tissue of lung cancer (21) and G-CSF stimulates the growth of tumor cells (22, 23) favors the malignant tumor. G-CSF, on the other hand, has neutrophil function enhancing activities such as oxygen radical generation $(24,25)$, chemotaxis (26) and antibody-dependent cellular cytotoxicity (24), which all may afford an antitumor effect. The influence exerted by these inconsistent activities on the disease states is of profound interest and will be further investigated.

Acknowledgements: We are grateful to the Research Laboratories of Chugai Pharmaceutical Co. Ltd. for the measurement of serum G-CSF.

\section{References}

1) Kawakami M, Tsutsumi H, Kumakawa $T$, et al. Levels of serum granulocyte colony-stimulating factor in patients with infections. Blood 76: 1962, 1990.

2) Watari $K$, Asano $S$, Shirafuji $N$, et al. Serum granulocyte colonystimulating factor levels in healthy volunteers and patients with various disorders as estimated by enzyme immunoassay. Blood 73: 117, 1989.

3) Kaushansky K, Lin N, Adamson JW. Interleukin 1 stimulates fibroblasts to synthesize granulocyte-macrophage and granulocyte colony-stimulating factors. Mechanism for the hematopoietic response to inflammation. J Clin Invest 81: 92, 1988.

4) Robinson WA. Granulocytosis in neoplasia. Ann NY Acad Sci 230: 212, 1974.

5) Asano $S$, Urabe A, Okabe $T$, et al. Demonstration of granulopoietic factor(s) in the plasma of nude mice transplanted with a human lung cancer and in the tumor tissue. Blood 49: 845, 1977.

6) Tohyama K, Yoshida Y, Kubo A, et al. Detection of granulocyte colony-stimulating factor produced by a newly established human hepatoma cell line using a simple bioassay system. Jpn J Cancer Res 80: 335, 1989.

7) Motojima H, Kobayashi T, Shimane M, Kamachi S, Fukushima M. Quantitative enzyme immunoassay for human granulocyte colony stimulating factor (G-CSF). J Immunol Methods 118: $187,1989$.

8) Lee MY, Kaushansky K, Judkins SA, Lottsfeldt JL, Waheed A, Shadduck RK. Mechanisms of tumor-induced neutrophilia: Constitutive production of colony-stimulating factors and their synergistic actions. Blood 74: 115, 1989.

9) Takaku F. Clinical significance of blood cell differentiation. 


\section{Serum G-CSF level in Cancer Patients}

Nippon Naika Gakkai Zasshi 75: 1043, 1986 (in Japanese).

10) Granström M. Studies on inhibitors of bone marrow colony formation in normal human sera and during a viral infection. Exp Cell Res 82: 426, 1972.

11) Hocking W, Goodman J, Golde D. Granulocytosis associated with tumor cell production of colony-stimulating activity. Blood 61: $600,1983$.

12) Sugiyama $H$, Yagita $M$, Takahashi $T$, et al. Type-specific in vitro growth patterns of multilineage hemopoictic progenitors in myeloproliferative disorders and myelodysplastic syndromes. Acta Haematol Jpn 50: 46, 1987.

13) Fukuda M. Studies on hematopoietic stem cells. CFUe and CFUe in chronic myeloproliferative disorders. Akita J Med 8: 381, 1982 (in Japanese).

14) Yoshihara $K$, Fukuyama $K$, Okamura $T$, et al. An autopsy case of CSF (colony-stimulating factor) producing lung cancer. Gan No Rinsho 32: 805, 1986 (in Japanese).

15) Sato N, Asano S, Koeffler P, Yoshida S, Takaku F, Takatani O. Identification of neutrophil alkaline phosphatase-inducing factor in cystic fluid of a human squamous cell carcinoma as granulocyte colony-stimulating factor. J Cell Physiol 137: 272, 1988.

16) Chikkappa G, Wang GJ, Santella D, Pasquale D. Granulocyte colony-stimulating factor (G-CSF) induces synthesis of alkaline phosphatase in neutrophilic granulocytes of chronic myelogenous leukemia patients. Leukemia Research 12: 491, 1988.

17) Rambaldi A, Tarao M, Bettoni $S$, et al. Expression of leukocyte alkaline phosphatase gene in normal and leukemic cells: Regulation of the transcript by granulocyte colony-stimulating factor. Blood 76: 2565, 1990.
18) Fujii H, Sonoda $Y$, Maekawa $T$. Two cases of CSF-producing lung tumor. Rinsho Ketueki 25: 1653, 1984 (in Japanese).

19) Sato K. A paraneoplastic syndrome of hypercalcemia and leukocytosis associated with solid tumors: Production of interleukin $1 \alpha$ and G-CSF by clonal squamous cell carcinoma cells. Nippon Naibunpi Gakkai Zasshi 64: 1223, 1988.

20) Bockman RS, Bellin A, Repo MA, Hickok NJ, Kameya T. In vitro and in vivo biological activities of two human cell lines derived from anaplastic lung cancers. Cancer Res 43: 4571, 1983.

21) Avalos BR, Gasson JC, Hedvat C, et al. Human granulocyte colony-stimulating factor: Biologic activities and receptor characterization on hematopoietic cell and small cell lung cancer cell lines. Blood 75: 851, 1990.

22) Berdel WF, Danhauser-Riedl S, Steinhauser G, Winton EF. Various human hematopoietic growth factors (inteleukin 3, GM-CSF, G-CSF) stimulate clonal growth of nonhematopoietic tumor cells. Blood 73: 80, 1989.

23) Segawa $K$, Ueno $Y$, Kataoka $T$. In vivo tumor growth enhancement by granulocyte colony-stimulating factor. Jpn J Cancer Res 82: 440, 1991.

24) Asano S, Ono M. Human granulocyte colony-stimulating factor: Its biological actions and clinical implication. Acta Haematol Jpn 50: 1550, 1987.

25) Nathan CF. Respiratory burst in adherent human neutrophils: Triggering by colony-stimulating factors CSF-GM and CSF-G. Blood 73: 301, 1989.

26) Wang JM, Chen ZG, Colella S, et al. Chemotactic activity of recombinant human granulocyte colony-stimulating factor. Blood 72: $1456,1988$. 